\title{
A CHROMIAN TOURMALINE FROM OUTOKUMPU, FINLAND
}

\author{
E. Peltola, Y. Vuorelainen and T. A. Häkli \\ Outokumpu Co, Outokumpu, Finland
}

\begin{abstract}
Chromian tourmaline, a member of the dravite group, has been encountered in the Cr-bearing skarns occurin 1 between the serpentinites and quartzites in the Outokumpu area, in association with chrome-bearing silicates ang oxides. The reported chromian tourmaline contains $\mathrm{C}_{2} \mathrm{O}_{3} 9.60 \%$. The mineral is trigonal with $\mathrm{a}_{o}=15.96 \AA, \mathrm{c}_{o}=7.2 \mathrm{~d}$ $\AA$ and $\mathrm{D}=3.101 \mathrm{~g} / \mathrm{cm}^{3}$. The chromian tourmaline is uniaxial, negative and very strongly pleochroic with $\omega=1.687$ and $\varepsilon=1.638$.
\end{abstract}

Chromian tourmaline was first described from the Urals by Cossa and Arzruni (1883). Later the mineral was also reported from the Krivoi Rog area by Shenderova (1955).

In the Outokumpu area, chromian tourmaline is associated with other chrome minerals which frequently characterize the contact skarns between serpentinites and quartzites or serpentinites and the quartz of the ore.

The geology of the Outokumpu region has been described by P. Haapala (1936) and V. O. Vähätalo (1953). The serpentinites are commonly enveloped by a thin dolomitic halo which, however, varies in thickness. Skarns occur frequently between the dolomitic halo and the quartzite. The serpentinites grade into quartzites through a sequence of rocks: serpentinite, dolomite, tremolite-bearing dolomite, tremolite skarn, diopside skarn and quartzite. The thickness of the transition zone varies from a few centimetres to several metres. Only locally are some members of the sequence lacking.

Serpentinite, dolomite halo and skarns invariably contain chrome. The following chrome minerals are met with: chrome tremolite, chrome diopside, uvarovite, fuchsite, chromite, zincian chromite (T. P. Thayer et. al., 1964) and more seldom tawmawite, chromian tourmaline, eskolaite $\left(\mathrm{Cr}_{2} \mathrm{O}_{3}\right)$, merumite and a ruby variety of corundum. Chrome minerals in Outokumpu have been described by Eskola (1933).

The mode of occurrence of the contact skarns and their mineral association indicates that serpentinites with metasomatic dolomite halos have obviously given rise to the chrome mineralization. The abundance of skarn minerals rich in $\mathrm{Mg}$ and $\mathrm{Cr}$ strongly supports this point of view. Skarns are to be considered as products of a thermometamorphism. They have been formed by a reaction between a dolomite-bearing serpentinite and quartzite or alternatively quartzbearing ore.

The chromian tourmaline reported in this paper occurs in the Outokumpu formation as tiny idiomorphic crystals and usually follows the chrome tremolite skarns in the hanging wall contact of the ore in association with chrome tremolite, zincian chromite, chrome-bearing biotite, uvarovite, fuchsite and accessory esko- 
TABLE 1.

Chemical composition, unit cell parameters and optical data for two Finnish chromian tourmalines

\begin{tabular}{|c|c|c|c|c|}
\hline Outokumpu & & & Kaavi & \\
\hline $\mathrm{SiO}_{2} \ldots \ldots \ldots \ldots \ldots \ldots \ldots$ & 36.60 & & 35.74 & \\
\hline $\mathrm{B}_{2} \mathrm{O}_{3} \ldots \ldots \ldots \ldots \ldots$ & 8.50 & $\omega=1.687$ & 10.30 & $\omega=1.685-1.687$ \\
\hline $\mathrm{Al}_{2} \mathrm{O}_{3} \ldots \ldots \ldots \ldots \ldots \ldots \ldots$ & 27.20 & $\varepsilon=1.638$ & 28.85 & $\varepsilon=1.639-1.642$ \\
\hline $\mathrm{Cr}_{2} \mathrm{O}_{3} \ldots \ldots$ & 9.60 & & 8.97 & \\
\hline $\begin{array}{l}\mathrm{V}_{2} \mathrm{O}_{5} \ldots \ldots \ldots \ldots \ldots \ldots \ldots \ldots \ldots \ldots \ldots \ldots \ldots \\
\mathrm{Fe}_{2} \mathrm{O}_{3} \ldots \ldots \ldots \ldots \ldots \ldots \ldots\end{array}$ & 0.61 & $\mathrm{D}=3.101 \mathrm{~g} / \mathrm{cm}^{3}$ & nil & $\mathrm{D}=3.13 \mathrm{~g} / \mathrm{cm}^{3}$ \\
\hline $\mathrm{FeO}$ & 0.13 & $a_{0}=15.96 \AA$ & 0.28 & $a_{o}=15.945 \AA$ \\
\hline $\mathrm{TiO}_{2} \ldots \ldots \ldots \ldots \ldots \ldots$ & 0.22 & $c_{o}=7.22 \AA$ & 0.28 & $c_{o}=7.202 \AA$ \\
\hline $\mathrm{MnO} \ldots \ldots \ldots \ldots \ldots \ldots \ldots$ & - & & traces & \\
\hline $\mathrm{MgO} \ldots \ldots \ldots \ldots \ldots \ldots$ & 10.60 & & 9.05 & \\
\hline $\mathrm{CaO}$ & 1.00 & & 1.22 & \\
\hline $\mathrm{SrO} \ldots \ldots \ldots \ldots \ldots \ldots \ldots$ & 0.34 & & - & \\
\hline $\mathrm{Na}_{2} \mathrm{O} \ldots \ldots \ldots \ldots \ldots \ldots$ & 2.00 & & 1.91 & \\
\hline $\mathrm{K}_{2} \mathrm{O} \quad \ldots \ldots \ldots \ldots \ldots \ldots \ldots \ldots$ & 0.05 & & 0.14 & \\
\hline $\mathrm{F} \ldots \ldots \ldots \ldots \ldots \ldots \ldots \ldots \ldots$ & traces & & 0.31 & \\
\hline $\mathrm{H}_{2} \mathrm{O}+\ldots \ldots \ldots \ldots \ldots \ldots \ldots$ & 2.97 & & 2.93 & \\
\hline \multirow[t]{4}{*}{$\mathrm{H}_{2} \mathrm{O}-\ldots \ldots \ldots \ldots \ldots \ldots$} & - & & 0.02 & \\
\hline & 99.82 & & 100.00 & \\
\hline & & $\mathrm{O}=\mathrm{F}$ & 0.14 & \\
\hline & & & 99.86 & \\
\hline
\end{tabular}

The Kaavi tourmaline was analysed by Y.L. Tong at the University of Leeds under the direction of Dr. O. Knorring.

laite and ruby corundum. No chromian tourmaline has been encountered in diopside skarns.

The analysed chromian tourmaline samples from Outokumpu also contain about $0.6 \%$ vanadium. According to Kouvo and Vuorelainen (1958) the Outokumpu eskolaite contains about $4 \%$ vanadium. More recent studies (Long, Vuorelainen and Kouvo, 1963) indicate that proper vanadium oxide minerals are also met with in the Outokumpu deposit (karelianite, $\mathrm{Mn}-\mathrm{V}$-spinel and nolanite). Moreover, merumite, which occurs as an alteration product of eskolaite (Vuorelainen, 1965) contains vanadium abundantly. The vanadium content of the Outokumpu serpentinites fluctuates from $0.008 \%$ to $0.016 \% \mathrm{~V}_{2} \mathrm{O}_{5}$. The boron tenor is roughly $0.005 \%$. The vanadium percentage in the ore varies from $0.003 \%$ to $0.03 \% \mathrm{~V}_{2} \mathrm{O}_{5}$, reaching the highest values near the contacts of the black schists. Locally, chromian tourmaline is also encountered in the black schists especially in the calcareous variants, but in that case its chrome content appears to be comparatively low. The boron content of the black schists varies from 0.001 to $0.1 \%$ B. (Peltola, 1968) which is frequently higher than that of the other metasediments in the area.

Dr. O. Knorring has kindly provided the authors with the analytical and optical data of a chromian tourmaline from Kaavi, about $40 \mathrm{~km}$ north of the Outokumpu area. This tourmaline occurs, contrary to the Outokumpu tourmaline, in a fuchsite gneiss. The data concerning the mineral are listed in Table 1.

The chromian tourmaline crystals are deep green, and in places, almost black in colour. Under the binocular microscope the grains appear as yellowish emerald green in colour and deep emerald green parallel to the c-axis. Strong ruby red internal reflections are observed frequently. In thin section, the chromian tourmaline is strongly peochroic, uniaxial and negative with $\omega=1.687$ (bluish emerald green) and $\varepsilon=1.638$ (yellow green). Crystals often show zonal structures in the cross sections due to the variation in the chrome content (see Fig. 1).

A pycnometer determination gave a density of $3.101 \mathrm{~g} / \mathrm{cm}^{3}$ for the Outokumpu chromian tourmaline. 


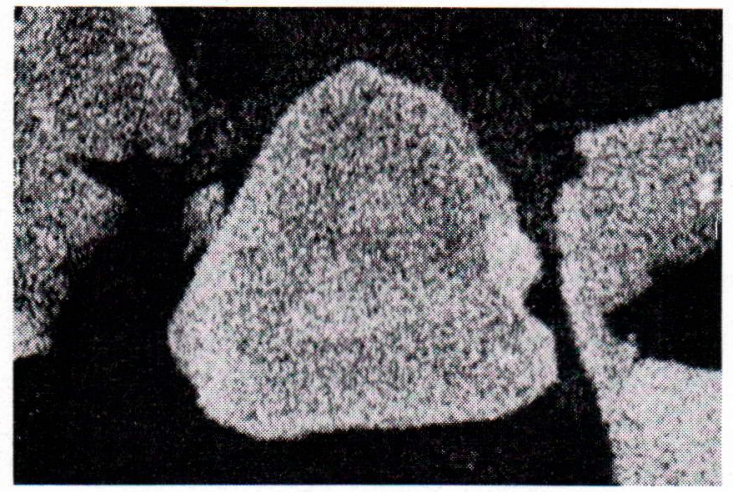

Fig. 1. X-ray scanning image showing the zonal distribution of $\mathrm{Cr}$ in a chromian tourmaline crystal. The chrome content is highest in the core and rim. Magnification $100 \mathrm{x}$.

The chemical composition of the chromian tourmaline in the Outokumpu area differs only slightly from those reported in literature. The most remarkable differences concern the relative high vanadium content and the almost total lack of fluorine in the former. Table 1 lists the chemical compositions of the Outokumpu and Kaavi chromian tourmalines.

The unit cell parameters of the chromian tourmaline were determined by means of the $\mathrm{X}$-ray diffraction technique using Ni-filtered copper radiation and silicon as an internal standard. The diffraction data of the Outokumpu chromian tourmaline are presented in Table 2.

Acknowledgements - The authors are grateful to the Outokumpu Co for permission to publish this paper. Dr. P. Haapala critically revised the manuscript and made valuable suggestions. Dr. O. Knorring kindly placed the
TABLE 2.

X-ray diffraction data for the Outokumpu chromian tourmaline

$\begin{array}{lrll}\text { hkl } & \mathrm{I} & \mathrm{d}(\AA) \text { obs. } & \mathrm{d}(\AA) \text { calc. } \\ 101 & 40 & 6.387 & 6.401 \\ 021 & 20 & 4.987 & 4.993 \\ 300 & 10 & 4.595 & 4.607 \\ 211 & 35 & 4.223 & 4.2326 \\ 220 & 45 & 3.979 & 3.990 \\ 012 & 100 & 3.494 & 3.4929 \\ 131 & 5 & 3.379 & 3.3858 \\ 401 & 5 & 3.1128 & 3.1169 \\ 410 & 5 & 3.0110 & 3.0162 \\ 122 & 75 & 2.9675 & 2.9700 \\ 321 & 5 & 2.9023 & 2.9032 \\ 312 & 10 & 2.6284 & 2.6281 \\ 051 & 50 & 2.5764 & 2.5777 \\ 042 & 5 & 2.4945 & 2.4963 \\ 241 & 5 & 2.4523 & 2.4538 \\ 003 & 15 & 2.4072 & 2.4067 \\ 232 & 15 & 2.3800 & 2.3824 \\ 511 & 10 & 2.3443 & 2.3476 \\ 600 & 5 & 2.3017 & 2.3036 \\ 502 & 5 & 2.1945 & 2.1948 \\ 431 & 5 & 2.1628 & 2.1675 \\ 303 & 25 & 2.1314 & 2.1332 \\ 422 & 5 & 2.1144 & 2.1162 \\ 223 & 15 & 2.0593 & 2.0608 \\ 152 & 30 & 2.0434 & 2.0233 \\ 161 & 5 & 2.0212 & 2.0233 \\ 440 & 5 & 1.9910 & 1.9928 \\ 342 & 35 & 1.9204 & 1.9231 \\ 701 & 5 & 1.9010 & 1.9044 \\ 413 & 10 & 1.8810 & 1.8812 \\ 621 & 10 & 1.8497 & 1.8526 \\ 612 & 5 & 1.8061 & 1.8203 \\ 104 & 15 & 1.7882 & 1.7898 \\ 333 & 5 & 1.7847 & 1.7846 \\ 024 & 5 & 1.7462 & 1.7464 \\ 532 & 5 & 1.7319 & 1.7323 \\ 541 & 5 & 1.7084 & 1.7188 \\ 262 & 5 & 1.6918 & 1.6929 \\ 603 & 50 & 1.6680 & 1.6642 \\ 271 & 20 & 1.6470 & 1.6442 \\ 550 & 15 & 1.5943 & 1.5940\end{array}$

analytical data concerning a chromian tourmaline from Kaavi, Finland at the authors' disposal.

\section{REFERENCES}

Cossa, A. and Arzruni, A. (1883). Zeit. Kryst. vol. 7. p. 1.

Eskola, P. (1933). On the chrome minerals of Outokumpu. Compt. rend. Soc. géol. Finlande. 7; Bull. Comm. géol. Fin. 103, 26.

Haapala, Paavo (1936). On serpentine Rocks in Northern Karelia: Bull. Comm. géol. Finlande, 114.

Kouvo, O., Vuorelainen, Y. (1958). Eskolaite, a new chromium mineral: Am. Mineral., 43, 1098.
Long, J. V. P., Vuorelainen, Y. and Kouvo, O. (1963). Karelianite, a new vanadium mineral. Am. Mineral. 48. $33-41$.

Peltola, Esko (1968). On some geochemical features in the black schists of the Outokumpu area, Finland. Bull. Geol. Soc. Finland 40, p. 42.

Shenderova, A. G. (1955) On chrome-bearing dravite from the Krivoi Rog region. Min. Sbornik Lvov. Geol. Soc., no 9. p. 324. 
Thayer, T. P.; Milton, Charles; Dinnin, Joseph and Rose, Harry. Jr. (1964). Zincian chromite from Outokumpu, Finland. Am. Mineral., 49. 1178-1183. Vuorelainen, Y. (1965). On the merumite as a pseudomorph after Eskolaite, Outokumpu, Finland. Manuscript to be published.
Vähätalo, Veikko (1953). On the geology of the Outokumpu ore deposit in Finland: Bull. Comm. geol. Finlande, 164.

Manuscript received, January 12, 1968. 